$\$$ Research Square
Preprints are preliminary reports that have not undergone peer review.

They should not be considered conclusive, used to inform clinical practice, or referenced by the media as validated information.

\title{
Aid for Trade and Real Exchange Rate in Recipient- Countries
}

\section{SENA KIMM GNANGNON ( $\nabla$ kgnangnon@yahoo.fr )}

World Trade Organization (WTO)

\section{Research Article}

Keywords: Aid for Trade, Non-Aid for Trade, Real exchange rate

Posted Date: March 8th, 2020

DOI: https://doi.org/10.21203/rs.3.rs-16500/v1

License: (a) (i) This work is licensed under a Creative Commons Attribution 4.0 International License.

Read Full License

Version of Record: A version of this preprint was published at The International Trade Journal on March 8th, 2020. See the published version at https://doi.org/10.1080/08853908.2021.1989349. 


\section{Abstract}

The current analysis contributes to the literature on the real exchange rate (RER) effect of development aid by separating out the RER effect of the development aid allocated to the trade sector - referred to as Aid for Trade (AfT) - from the effect of NonAfT flows. The empirical findings show that AfT flows exert a RER depreciation in recipient-economies, while NonAfT flows are associated with a RER appreciation. From a policy perspective, these results show that scaling-up AfT flows could promote countries' competitiveness in the international trade market through a greater extent of RER depreciation.

\section{Introduction}

In spite of the voluminous literature on the Dutch Disease matter, a relatively limited number of studies[1] has been devoted to the effect of development aid (also referred to as official development aid - ODA) on real exchange recipient-countries. Among these studies, some have found that development aid inflows have led to an appreciation of the real exchange rate in the recipient-countries (e.g., Addison and Baliamoune-Lutz, 2017; Adu and Denkyirah, 2018; Edwards and van Wijnbergen, 1989; Elbadawi, 1999; Ouattara and Strobl, 2008; Rajan and Subramanian, 2011; Van Wijnbergen, 1984; Vos, 1998; White, 1992; White and Wignaraja, 1992; Younger, 1992). Other studies have uncovered a real exchange rate depreciation effect of development aid inflows (e.g., Arhenful, 2013; Li and Rowe, 2007; Nkusu, 2004; Nyoni, 1998; Sackey, 2001; Selaya and Thiele, 2010). Issa and Ouattara (2008) have obtained no significant Dutch disease effect of development aid in the short-run or long-run in developing countries. Berg et al. (2005) have argued that the use of aid flows on tradable goods (i.e. import of investment goods and those with limited offer) may not induce an exchange rate overvaluation. Along the same lines, Adam and Bevan (2006) have shown that while the Dutch disease may materialize in the short-run, the correlation between increased aid inflows, real exchange rate and welfare could be much complex than suggested by simple models.

Theoretically, the main channel through which development aid can influence the recipient-country's real exchange rate - at least in the short-run - is the relative price of non-tradables to tradables. In other words, the effect of development aid inflows on the tradables sector relatively to the non-tradables sector is crucial for determining the impact of these inflows on the real exchange rate, at least in the short-run, in the recipient-economy. While the afore-mentioned literature has mainly focused on the effect of total development aid inflows on real exchange rate in the recipient economy, it could desirable to examine whether the part of the total ODA allocated to the trade sector in the recipient-country exerts a different effect on real exchange rate from other aid flows (that is, the development aid allocated to other sectors in the recipient-economy). The attention devoted by the international trade community to the development aid allocated to the trade sector in developing countries arises from the realization by the Members of the World Trade Organization (WTO) that developing countries, including Least developed countries (LDCs) experience significant structural impediments that prevent them from expanding trade. The AfT Initiative has, therefore, been set up by WTO Members at the 2005 WTO Hong Kong Ministerial Conference, with a view to "helping developing countries, particularly LDCs build the supply-side capacity 
and trade-related infrastructure that they need to assist them to implement and benefit from WTO Agreements and more broadly to expand their trade" (see Paragraph 57 of the Hong Kong Ministerial Declaration, see WTO, 2005). Many studies have reported the positive effect of AfT flows on the trade sector of recipient-countries, in particular on these countries' export performance (see Cadot et al. 2014 and OECD-WTO, 2017 for a literature review on AfT effectiveness). This, therefore, suggests that by expanding the tradable sector, AfT flows could be associated with a depreciation of the real exchange rate. However, as NonAfT flows are allocated to the non-trade sector in the recipient-economy, and hence potentially on non-tradables sector, these inflows could lead to an appreciation of the real exchange rate.

The current analysis investigates the effect of AfT flows on the real effective exchange rate in the recipient-countries, in an attempt to examine whether AfT flows and NonAfT flows influence differently the real exchange rate. The analysis covers a panel dataset of 113 AfT recipient-countries (of which 35 LDCs) over the period 1996-2016. It has shown that AfT flows have led to a depreciation of the real exchange rate, while NonAfT flows have been associated with an appreciation of the real exchange rate.

The remaining part of the analysis is split into four sections. Section 2 provides a theoretical discussion on how AfT flows could affect the real exchange rate in recipient-countries. Section 3 presents the model specification that helps examine the effect of AfT flows on real exchange rate, and briefly discusses the econometric methodology used to perform the empirical analysis. Section 4 discusses the empirical results, and Section 5 concludes.

Footnote

[1] These studies include for example Adams (2005); Adam and Bevan (2004); Addison and BaliamouneLutz (2017); Adu and Denkyirah (2018); Arhenful (2013); Elbadawi (1999); Edwards and van Wijnbergen (1989); Issa and Ouattara (2008); Li and Rowe (2007); Nkusu (2004); Nyoni (1998); Ouattara and Strobl (2008); Radelet (2006); Rajan and Subramanian (2011); Sackey (2001); Selaya and Thiele (2010); Van Wijnbergen (1985); Vos (1998); White (1992); White and Wignaraja (1992); Younger (1992).

\section{Theoretical Motivation On The Impact Of Aft On Real Exchange Rate}

The theoretical literature on the real exchange rate effect of development aid inflows has drawn from the standard Dutch Disease theory, which is a theory of demand-side impact of a capital inflow (e.g., Addison and Baliamoune-Lutz, 2017). The basic theory of the Dutch Disease considers two sectors, i.e., a tradables sector and a non-tradables sector (e.g., Addison and Baliamoune-Lutz, 2017). Therefore, the relative price of the non-tradables to tradables represents the real exchange rate (e.g., Bruno and Sachs, 1982; Corden, 1981, 1984; Corden and Neary, 1982). The model also assumes that the economy that receives a capital inflow is a small open economy, i.e., the economy is a price-taker in the world market. 
Further to a capital inflow, including for example an inflow of development aid, aggregate demand would rise, depending on the extent to which such aid is used by the Central Bank to affect the monetary base. As the prices in the tradables market are by assumption fixed, whereas prices in the non-tradables market are determined by the domestic supply and demand, further to capital inflows the tradable market would clear by a quantity adjustment and the non-tradables market would clear by an upward price adjustment. This process would, therefore, lead to a real appreciation of the real exchange rate (i.e., the increase in the relative price of non-tradables to tradables). Productive factors, including labour would then shift from the tradables sector to the non-tradables sector. Additionally, this real exchange rate appreciation could be further strengthened if the rise in capital inflow was associated with the appreciation of the nominal exchange rate. The effect of real exchange rate appreciation on the output of tradables versus output of non-tradables depends on whether the economy is operating on its production-possibility frontier (PPF) (i.e., whether it makes a full use of its productive factors) or whether it is operating within its PPF. Four cases have been outlined in that regard (e.g., Addison and Baliamoune-Lutz, 2017). First, if the economy is on the PPF, the real exchange rate appreciation induced by the capital inflows would expand the share of output in non-tradables, thanks to the move of productive factors away from the tradables sector to the non-tradables sector. Second, if the economy operates inside the PPF (which is the case for the majority of developing countries), both output of tradables and output of non-tradables may rise (although not necessarily in the same proportion) further to rise in the aggregate demand associated with the capital inflow. Third, in the event the supply of non-tradables is less elastic than the supply of tradables, the relative price of non-tradables to tradables would move at the benefit of non-tradables, although to a lower extent if the economy were operating on its PPF. Finally, the capital inflow could be used to augment the recipient-country's productive capacity (which would shift the PPF upward), reduce its supply-side constraints, and ultimately expand its production and exports. In this scenario, the capital inflow could lead to a greater expansion of the tradables sector compared to the non-tradables sector, and result in a depreciation of the real exchange rate.

Against this backdrop, we now analyse how AfT flows and NonAfT flows (which summing up constitute total ODA flows) affect the real exchange rate in recipient-countries. According to the Organization of Economic Cooperation and Development (OECD), AfT flows are classified into three categories: AfT allocated for economic infrastructure, AfT allocated for building productive capacity, and AfT for trade policy and regulation. Sectors covered by the first category of AfT include transport and storage, communications, and energy generation and supply. AfT dedicated to building productive capacity covers the sectors of banking and financial services, business and other services, agriculture, fishing, industry, mineral resources and mining, and tourism. Trade policy and regulation and trade-related adjustment interventions are included in the category of AfT for trade policy and regulation. Hence, in contrast with other development aid inflows (referred to as NonAfT flows), AfT flows target the tradable sector in recipient-countries, with a view to expanding it and promoting countries' integration into the global trading system. As a result, AfT flows are unlikely to be fungible, or at least less fungible than NonAfT flows (e.g., Bearce et al. 2013). NonAfT flows include development aid allocated, inter alia, to humanitarian assistance, construction, the accumulation of human capital (i.e., the enhancement of 
better education and health) and institutional improvement. Therefore, this type of aid inflows would contribute to the expansion of the non-tradables sector, and consequently lead to an appreciation of the real exchange rate.

From a theoretical viewpoint, AfT flows promote countries' trade performance by strengthening international competitiveness of recipient-countries' trading firms, notably through the reduction of trade costs, the expansion of productive capacities, and greater liberalization of trade policies in line with countries' export development strategy. In supporting of this argument, many studies have reported that AfT inflows could positively affect recipient-countries trade performance, including export performance measured in terms of exports and imports of goods and services (or exports of goods, including manufacturing and primary goods) (e.g., Bearce et al., 2013; Busse et al., 2012; Cadot et al. 2014; Calì and te Velde, 2011; Gnangnon, 2019a; Ghimire et al., 2016; Helble, et al., 2012; Hoekman, and Shingal, 2017; Hühne et al., 2014a; 2014b; Hynes and Holden, 2016; Martínez-Zarzoso et al., 2017; Vijil, 2014; Vijil and Wagner, 2012) or export product diversification/economic complexity (e.g., Gnangnon, 2019b, 2019c; Kim, 2019). We, therefore, hypothesize that as it is invested to promote the expansion of the tradables sector, AfT flows could be associated with real exchange rate depreciation in the recipient-countries.Specially, AfT allocated to the development of economic infrastructure in recipient-countries is the dominant category of AfT flows. Even though it does not target a specific export sector, and is therefore sectorneutral (e.g. Cirera and Winters, 2015), it significantly contributes to reducing trade costs through the build-up of hard infrastructure (such as physical infrastructure, i.e., roads and ports, and information and communication technology - ICT - tools) that is essential for promoting trade performance, including export performance. AfT flows allocated to trade policy and regulation also contribute to reducing administrative costs and regulatory bottlenecks to trade (e.g., Busse et al., 2012; Calì and TeVelde, 2011). This type of AfT helps enhance the border and transport efficiency through streamlining the time, cost, and number of documents necessary for export and import procedures, and thus facilitate the movement of cross-border trade flows. The adverse effect on trade performance (including export performance) of the lack of trade facilitation (through hard and soft infrastructure) has been emphasized by many authors in the literature (e.g., Anderson and Marcouiller, 2002; Busse et al., 2012; Calì and TeVelde, 2011; Limao and Venables, 2001; Portugal-Perez and Wilson, 2012; Wilson et al., 2003, 2005). Thus, by helping recipient-countries enhance their export performance, the trade facilitation effect of AfT flows for economic infrastructure and AfT flows for trade policy and regulation could lead to a depreciation of the real exchange rate. AfT flows allocated to trade policy and regulation also helps expand recipientcountries' trade performance by contributing to strengthen the capacity of policymakers in recipientcountries to implement appropriate trade policies commensurate with the export development strategies and the WTO's rules. This could also result in a depreciation of the real exchange rate. AfT flows allocated for strengthening productive capacity are essentially used to expand the recipient-countries' productive capacity. As a result, it would expand the recipient-country's production and exports, and lead to the expansion of the tradables sector relative to the non-tradables sector. This would induce a depreciation of the real exchange rate. Furthermore, Gnangnon (2018) has reported empirical evidence that total AfT flows interventions, including AfT interventions for economic infrastructure, AfT 
interventions for productive capacity and AfT interventions for trade policy and regulations are associated with greater trade policy liberalization. As the latter is associated with the expansion of the tradable sector-in particular through higher exports - relative to the non-tradables sector, we expect that the AfT variables could result in the depreciation of the real exchange rate.

Overall, we expect that as they contribute to the expansion of the tradables sector relative to the nontradables sector, total AfT flows, as well as all its three components would likely be associated with the depreciation of the real exchange rate.

\section{Model Specification}

We investigate the effect of AfT flows (and NonAfT flows) on real exchange rate by drawing from the studies highlighted above that have considered the effect of development aid on real exchange rate. In addition to the variables capturing AfT flows and NonAfT flows, the model specification contains the standard and well-established other variables that can potentially influence the real exchange rate movements in developing countries (e.g., Addison and Baliamoune-Lutz, 2017; Ouattara and Strobl, 2008). These include general government final consumption expenditure, in percentage of GDP (denoted "GCONS"); Gross fixed capital formation in percentage of GDP (denoted "GFCF"), which is a proxy for public investment; a measure of trade openness (denoted "OPEN"); the broad money, in percentage of GDP (denoted "BRMONEY"), which is a measure of the money supply (M2); a measure of terms of trade (denoted "TERMS") and the real per capita income (denoted "GDPC"), which also acts as a proxy for the development level. All variables these have been described in Appendix 1.

The dependent variable, i.e., the real effective exchange rate index (denoted "REER") is extracted from the Bruegel datasets (see Darvas, 2012a, 2012b). It has been computed for a given country as the nominal exchange rate (which is a geometrically weighted average of the bilateral exchange rates between this country and its trading partners) multiplied by the consumer price index of the concerned country in period $t$, and divided by the geometrically weighted average of the consumer price indexes of its trading partners over the same period. The nominal effective exchange rate is based on 66 trading partners. An increase in REER indicates an appreciation of the real effective exchange rate, i.e., an appreciation of the home currency against the basket of currencies of trading partners, while a decrease in REER reflects a depreciation of the real effective rate.

The regressor of interest in the analysis, i.e, AfT flows is denoted "AfT", and acts as the measure of the real gross disbursements of AfT flows. "AfT" is measured either by the total real gross disbursements AfT flows (constant US dollar 2016 prices) denoted "AfTTOT" or its components. These components include the real gross disbursements AfT flows for economic infrastructure (constant US dollar 2016 prices) denoted "AfTINFRA", the real gross disbursements of AfT flows for building productive capacity (constant US dollar 2016 prices) denoted "AfTPROD", and the real gross disbursements of AfT flows allocated for trade policies and regulation (constant US dollar 2016 prices) denoted "AfTPOL". The OECD/CRS (Creditor Reporting System) database provides data on the gross disbursements of AfT flows that spans the 
period from 2002 onwards. When the present study was written, AfT data available covered the period 2002-2016. Given that this period is relatively short for allowing to capture the medium-term effect of AfT flows (and NonAfT flows) on real exchange rate, we follow the approach proposed by Clemens et al. (2012), Thiele et al. (2006) and Selaya and Sunesen (2012, p2158)to expand the database using AfT commitments data.This approach is described in Appendix 2. Our final dataset on AfT flows (as well as its components) cover the period 1996-2016. The variable "NonAfT" that captures the real total gross disbursements of NonAfT flows (constant US dollar 2016 prices) has been computed as the difference between the gross disbursements of total ODA and the gross disbursements of total Aid for Trade (both being expressed in constant prices 2016, US Dollar).

In light of the foregoing, we consider the following model:

$$
\begin{aligned}
& \text { REER }_{i t}=\alpha_{0}+\alpha_{1} \text { REER }_{i t-1}+\alpha_{2} \text { AfT }_{i t}+\alpha_{3} \text { NonAfT }_{i t}+\alpha_{4} G_{F C F_{i t}}+\alpha_{5} \mathrm{GCONS}_{i t}+\alpha_{6} \text { OPEN }_{i t}+ \\
& \alpha_{7} \text { BRMONEY }_{i t}+\alpha_{8} \text { GDPC }_{i t}+\alpha_{9} \text { TERMS }_{i t}+\mu_{i}+\gamma_{t}+\omega_{i t}
\end{aligned}
$$

The panel dataset is unbalanced and contains 113 AfT recipient-countries (of which 35 LDCs) over the period 1996-2016, based on data availability on the variables contained in model (1). To smooth out the effect of business cycles on these variables, we have used non-overlapping sub-periods of 3-year average data (1996-1998; 1999-2001; 2002-2004; 2005-2007; 2008-2010; 2011-2013; and 2014-2016). The subscript $i$ in model (1) represents the index for a given country, while the subscript $t$ is associated with the time-period, i.e., each of the aforementioned 7 time-periods. a0 to a9 are parameters to be estimated. $\mu \mathrm{i}$ are countries' fixed effects; $\gamma t$ are time dummies, which represent global shocks that affect simultaneously all countries' real exchange rate. wit is a well-behaving error term. The natural logarithm has been applied to all variables contained in model (1).

Let us briefly discuss the expected effect of control variables on real exchange rate. According to Balassa (1964) and Samuelson (1964), as countries develop, the improvement of their productivity in the tradables (goods) sector exceeds that of the non-tradables (goods) sector, and leads to a higher price of non-tradables relatively to tradables. Therefore, the Balassa-Samuelson hypothesis posits that a higher real per capita income induces an appreciation of the real exchange rate.

The effect of government consumption/expenditure on real exchange rate depends on whether it is spent on tradables or on non-tradables. A higher consumption on non-tradables would be associated with the real exchange rate appreciation, while consumption of tradables would result in a depreciation of the real exchange rate. Overall, the effect of government consumption on real exchange rate is an empirical matter. Nonetheless, according to a number of empirical studies (e.g., Corsetti and Müller, 2006; Galstyan and Lane, 2009), government consumption is geared towards non-tradables goods, which suggests that it would be associated with an appreciation of the real exchange rate. At the same time, Ravn et al. (2012) and Monacelli and Perotti (2010) have obtained that an increase in government spending generates a real depreciation of the domestic currency. Along the same lines, a rise in public investment in tradables (non-tradables) would be associated with a depreciation (appreciation) of the real exchange 
rate (see for example Ouattara and Strobl, 2008). Incidentally, a rise in the money supply would lead to a higher level of the general domestic price, and hence in the appreciation of the real exchange rate.

The effect of trade openness on real exchange rate is ambiguous. On the one hand, by limiting the import volumes, restrictive trade policies would cause a rise in the prices of non-tradables and hence an appreciation of the real exchange rate. In contrast, trade liberalization (or greater trade openness) would foster competition and cause a depreciation of the real exchange rate. On another note, greater trade openness could enhance productivity gains (e.g., Camarero et al., 2015; Frankel and Romer, 1999; Kappeler, 2015; Hufbauer and Lu, 2016; Melitz 2003), which would contribute to the expansion of the tradables sector and lead to the depreciation of the real exchange rate.

The impact of terms of trade on real exchange rate depends on two opposite effects, namely an income effect of terms of trade and a substitution effect of terms of trade, which both are reflected in a higher demand for non-tradables. If the income effect dominates, then an improvement in terms of trade would lead to a real exchange rate appreciation. However, if the substitution effect dominates, terms of trade improvement would be associated with a depreciation of the real exchange rate. Authors such as Edwards (1988) have noted that the income effect is likely to dominate the substitution effect, potentially leading the terms of trade improvement to result in an appreciation of the real exchange rate. A real exchange rate appreciation effect has recently been reported (in particular for Tunisia) by Addison and Baliamoune-Lutz (2017).

Using non-overlapping data over the period 1996-2016, we provide in Figure 1 the development of the key variables of interest in the analysis (the average values of these variables over the non-overlapping sub-periods have been used). These include the variables "REER" and "AfTTOT" as well as the share of total AfT flows in the real gross disbursements of total ODA flows. The Figure suggests that after a depreciation from 1996-1998 to 2002-2004, the real effective exchange rate has exhibited an upward trend over the rest of the period, thereby suggesting that AfT recipient-countries have experienced a real exchange rate appreciation from 2005-2007 to 2014-2016. At the same time, total AfT flows and the share of total AfT flows in the real gross disbursements of ODA flows have moved in the same direction over the entire period. Specifically, total AfT flows have declined substantially from US\$ million 307.5 in 1996-1998 to US\$ million 108.6 in 2002-2004, after which these inflows have exhibited an upward trend to reach US\$ million 280.47 in 2014-2016. After a slight rise in the share of total AfT flows in total ODA from $46.8 \%$ in $1996-2008$ to $51.16 \%$ in $1999-2001$, this share has substantially declined to $14.47 \%$ in 2002-2004, and then exhibit an upward trend to reach $28.05 \%$ in 2014-2016. These positive movements of AfT flows and the share of total AfT flows in total ODA after 2004 is likely associated with the positive effect of the launch of the AfT Initiative with a view to mobilizing higher financial resources in favour of the trade sector in developing countries (see Gnangnon, 2019d).

With regard to the econometric approach used to estimate model (1), we use the two-step system Generalized Methods of Moments (GMM) estimator developed by Arellano and Bover (1995) and Blundell and Bond (1998) (see also Ouattara and Strobl, 2008 who have employed this technique in their 
analysis). Using the two-step system GMM approach involves estimating a system of equations, which combines an equation in levels and an equation in differences (first differences), where lagged values are used as instruments for the first-differenced regressors, and first-differences are utilized as instruments for the equation levels. This estimator is appropriate for dynamic panel models (including with the lag of the dependent variable as regressor) with small time dimension and large cross-section, and where series exhibit a strong persistence over time (this is in particular the case in the current analysis). It allows for controlling for country-specific heterogeneity and the potential endogeneity (i.e., reverse causality or simultaneity bias) of the regressors, and as a result, helps uncover the causal effects of variables under analysis. Moreover, the two-step system GMM procedure helps tackle the endogeneity bias introduced by the correlation between the one-period lag of the dependent variable and countries' specific effects, i.e., the Nickell bias (Nickell, 1981). Following the empirical literature on the real exchange rate effects of development aid, and particularly the work by Ouattara and Strobl (2008), all variables, including the "AfT", "NonAfT" and control variables have been considered as endogenous. In particular, the regressions have used 3 lags of the dependent variable as instruments and 2 lags of endogenous variables as instruments. Three diagnostic tests have been used to assess the validity of the two-step system GMM estimator. The consistency of this estimator is evaluated using the Arellano-Bond (AB) test of presence of first-order serial correlation in the error term (denoted $A R(1)$ ) and no second-order autocorrelation in the residuals (denoted AR(2)), and the Sargan/Hansen test of over-identifying restrictions (OID). This consistency rests on the non-rejection of the null hypotheses of these tests. We also report the number of instruments used in the regressions, as a higher number of instruments than the number of countries could make less powerful the aforementioned diagnostic tests (e.g., Roodman, 2009).

Table 1 reports the results of the estimation of model (1) where the variable "AfT" is alternatively measured by total AfT flows and each of its three components. In Table 2, we provide the outcomes of the estimation of different variants of model (1) that allow assessing the effect of AfT flows (total AfT flows variable and each of its components) on real exchange rate in LDCs versus NonLDCs. To do so, we estimate different specifications of model (1) that include each AfT variable (introduced once) (total AfT flows, and its components) along with its interaction with a dummy capturing LDCs. This dummy is denoted "LDC" and takes the value "1" for countries included in the category of LDCs[1], and "0", otherwise.

\section{Footnote}

[1] The list of countries contained in the category of LDCs is maintained by the United Nations, which considers LDCs as the poorest and most vulnerable countries in the world to economic and environmental shocks (for further information, see online at: http://unohrlls.org/)

\section{Interpretation Of Empirical Results}


The diagnostic tests to check the consistency of the two-step system GMM approach show full satisfactory results (see the bottom of Table 1 and 2). In addition, the lag of the dependent variable exhibits a positive and significant (at the 1\%) effect, which highlights the relevance of considering model (1) in a dynamic setting. Results in column [1] of Table 1 show a negative and statistically significant coefficient (at the $1 \%$ level) of the variable "AfTTOT" (in Logs). This suggests that a rise in total AfT flows lead to a depreciation of the real effective exchange rate: a 1 percentage increase in total AfT flows induces a 0.06 percentage decrease in the real effective exchange rate. This negative effect of total AfT flows on the real exchange rate is confirmed across the three other columns of Table 1 , which contain results of the estimation of specifications of model (1) with each of the components of total AfT flows. Specifically, the estimates associated with variables "AfTINFRA", AfTPROD", and "AfTPOL" are all negative and statistically significant at the $1 \%$ level. These suggest that AfT interventions for building economic infrastructure, AfT interventions for enhancing productive capacity, and AfT flows allocated for trade policy and regulation lead to a depreciation of the real effective exchange rate. In terms of magnitude of the impact of AfT components, we obtain that a 1 percentage increase in AfT flows for economic infrastructure leads to a 0.03 percentage decrease in the real effective exchange rate; a 1 percentage increase in AfT flows for productive capacity building generates to a 0.05 percentage decrease in the real effective exchange rate; and finally, a 1 percentage increase in AfT flows allocated for trade policy and regulations is associated with a 0.008 percentage decrease in the real effective exchange rate. Interestingly, among the components of total AfT flows, AfT flows allocated for productive capacity appear to exert the highest magnitude of the real exchange rate depreciation effect, followed by AfT for economic infrastructure, and AfT for trade policy and regulation. Across the three columns of Table 1, the coefficient of "NonAfT" variable is positive and statistically significant at the $1 \%$ level, thereby suggesting, as expected, that higher NonAfT flows are associated with an appreciation of the real effective exchange rate. With regard to control variables and focusing specifically on results in column [1] of Table 1, we obtain that while public investment is associated with the appreciation of the real effective exchange rate (but only at the $10 \%$ level), an increase in government consumption and greater trade openness induce a depreciation of the real effective exchange rate. At the same time, the rise in the money supply and terms of trade improvements are associated with the real effective exchange rate appreciation. Finally, real per capita income is positively associated with the appreciation of the real effective exchange rate, but this effect is significant only at the $10 \%$ level. Results concerning control variables in the three other columns of Table 1 (i.e., columns [2] to [4]) are quite similar to those in column [1] of the same).

We now turn to the outcomes reported in Table 2. Results in the four columns of this Table suggest that all AfT variables (total AfT flows and its components) exert a higher depreciating effect on the real effective exchange rate in LDCs than in NonLDCs (all effects are statistically significant at the $1 \%$ level). In particular, the net effects of total AfT flows interventions, AfT flows for economic infrastructure, AfT flows for productive capacity, and AfT for trade policy and regulations on real effective exchange rate in LDCs amount respectively to $-0.077(=-0.0637-0.0134),-0.047(=-0.0292-0.0176),-0.073(=-$ $0.0476-0.0250)$ and $-0.014(=-0.00441-0.00953)$. For NonLDCs, the net effects of total AfT flows 
interventions, AfT flows for economic infrastructure, AfT flows for productive capacity, and AfT for trade policy and regulations on real effective exchange rate amount respectively to $-0.0637,-0.0292,-0.0476$ and -0.0044 . The outcomes on the total AfT components suggest that for both LDCs and NonLDCs, the AfT component that contributes the most to the real exchange rate depreciation is AfT interventions for building productive capacity. This is followed by AfT interventions for enhancing economic infrastructure, and AfT flows for trade policy and regulations.

Results related to control variables in the four columns of Table 2 are in line with those presented in column [1] of Table 1, with the exception that in Table 2, public investment tends to be positively associated with real exchange rate appreciation, while the real per capita income is associated with the depreciation of the real effective exchange rate.

\section{Conclusions}

This paper has contributed to the literature on the real exchange rate effect of development aid by assessing the effect of AfT flows versus NonAfT flows on real exchange rate in recipient economies. The analysis has been carried out using a sample of 113 countries over the period 1996-2016. The findings indicate that for the full sample, both total AfT flows and the components of the latter exert a depreciating effect on real exchange rate. Furthermore, the AfT component that exerts the highest depreciating effect on real exchange rate is AfT flows allocated to building productive capacity. It is followed by AfT for economic infrastructure and AfT for trade policy and regulations. These outcomes apply to both LDCs and NonLDCs, and LDCs appear to enjoy a higher real exchange rate depreciating effect of AfT variables than do NonLDCs. At the same time, NonAfT flows have induced an appreciation of the real exchange rate.

As noted above, the empirical literature on the effect of total development aid on real exchange rate has been inconclusive. The present analysis has shown that in the envelope of total development aid, aid allocated to the trade sector exerts a depreciating effect on real exchange rate, which contributes to promoting the international competitiveness of trading firms, while other aid flows are associated with an appreciation of the real exchange rate, which undermines the country's international competitiveness.

\section{References}

Adam, C., and Bevan, D. (2006). Aid and the supply side: Public investment, export performance, and dutch disease in low-income countries. World Bank Economic Review, 20, 261-290.

Adams, C. S. (2005). “Exogenous Inflows and Real Exchange Rates: Theoretical Quirk or Empirical Reality?" Seminar organized by the International Monetary Fund (IMF) on Foreign Aid and Macroeconomic Management in Maputo, Mozambique, March 14-15, 2005.

Addison, T., and Baliamoune-Lutz, M. (2017). Aid, the Real Exchange Rate and Why Policy Matters: The Cases of Morocco and Tunisia, The Journal of Development Studies, 53(7), 1104-1121. 
Adu, D. T., and Denkyirah, E. K. (2018). Foreign aid - real exchange rate Nexus: Empirical evidence from Ghana. Cogent Economics \& Finance, 6(1), Article: 1499184.

Anderson, J. E., Marcouiller, D. (2002). Insecurity and the pattern of trade: an empirical investigation. Review of Economics and Statistics, 84(2), 342-52.

Arellano, M., and Bond, S. (1991). Some tests of specification for panel data: Monte Carlo evidence and an application to employment equations. Review of Economic Studies 58, 277-298.

Arellano, M., and Bover, O. (1995). Another look at the instrumental variable estimation of errorcomponents models. Journal of Econometrics, 68(1), 29-51.

Arhenful, P. (2013). The effect of foreign aid on real exchange rate in Ghana. Advances in Management and Applied Economics, 3(5), 151-169.

Balassa, B. (1964). The Purchasing-Power Parity Doctrine: A Reappraisal. Journal of Political Economy 72(6), 584-596.

Bearce, F., Pérez-Liñán, D. S. E., Rodríguez-Zepeda, J. A., and Surzhko-Harned L. (2013). Has the New Aid for Trade Agenda been Export Effective? Evidence on the Impact of US AfT Allocations 1999-2008. International Studies Quarterly, 57(1), 163-170.

Berg, A., Hussain, M., Aiyar, S., Roache, S., and Mahone, A. (2005). The Macroeconomics of managing increased aid inflows: Experiences of low-income Countries and policy implications. Washington: IMF.

Blundell, R., and Bond, S. (1998). Initial Conditions and Moment Restrictions in Dynamic Panel Data Models. Journal of Econometrics, 87, 115-143.

Bruno, M., and Sachs, J. (1982). Energy and resource allocation: A dynamic model of the 'dutch disease'. The Review of Economic Studies, 49, 845-859.

Busse, M., Hoekstra, R. and Königer, J. (2012). The impact of aid for trade facilitation on the costs of trading. Kyklos, 65(2), 143-163.

Cadot, O., Fernandes, A., Gourdon, J., Mattoo, A., and de Melo, J. (2014). Evaluating Aid for Trade: A Survey of Recent Studies. The World Economy, 37(4), 516-529.

Calì, M. and TeVelde, D. (2011). Does Aid for Trade Really Improve Trade Performance? World Development, 39(5), 725-740.

Camarero, M., Martínez-Zarzoso, I., Nowak-Lehmann, F., and Tamarit, C. (2015). Trade Openness and Income: A Tale of Two Regions. The World Economy, 39(3), 386-408.

Cirera, X., and Winters, L. (2015). Aid for trade and structural transformation in Sub-Saharan Africa (Commonwealth Trade Policy Discussion Papers, No. 2015/01). Retrieved from Commonwealth 
Secretariat website: https://doi.org/10.14217/5js6b1/p69ms-en

Clemens, M., Radelet, S., Bhavnani, R., and Bazzi, S. (2012). Counting chickens when they hatch: The short-term effect of aid on growth. Economic Journal, 122(561), 590-617.

Corden, W. M. (1981). The exchange rate, monetary policy and north sea oil. Oxford Economic Papers, 33, 23-46.

Corden, W. M. (1984). Boom sector and dutch disease economics: Survey and consolidation. Oxford Economic Papers, 36, 359-380.

Corden, W. M., and Neary, J. P. (1982). Booming sector and de-industrialisation in a small open economy. The Economic Journal, 92, 825-848.

Corsetti, G., and Müller, G. J. (2006). Twin deficits: Squaring theory, evidence, and common sense. Economic Policy, 48, 598-638.

Darvas, Z. (2012a). Real effective exchange rates for 178 countries: a new database. Working Paper 2012/06, Bruegel, Belgium.

Darvas, Z. (2012b). Compositional effects on productivity, labour cost and export adjustment. Policy Contribution 2012/11, Bruegel, Belgium.

Edwards, S. (1998). Openness, productivity, and growth: what do we really know? Economic Journal, 108 (447), 383-398.

Edwards, S., and van Wijnbergen, S. (1989). Disequilibrium and structural adjustment. Handbook of Development Economics, 2, 1481-1533.

Elbadawi, I. (1999). External aid: Help or hindrance to export orientation in Africa? Journal of African Economies, 8, 578-616.

Frankel, J. A. and Romer, D. (1999). Does Trade Cause Growth? American Economic Review, 89 (3), 379399.

Galstyan, V., and Lane, P. R. (2009). The composition of government spending and the real exchange rate. Journal of Money, Credit and Banking, 41(6), 1233-1249.

Ghimire S., Mukherjee, D. and Alvi, E. (2016). Aid-for-Trade and Export Performance of Developing Countries. Applied Econometrics and International Development, Vol. 16-1.

Gnangnon, S. K. (2018). Aid for trade and trade policy in recipient countries. The International Trade Journal, 32(5), 439-464. 
Gnangnon, S. K. (2019a). Aid for Trade and Recipient-Countries' Export Structure: Does Trade Policy Liberalization Matter? Arthaniti: Journal of Economic Theory and Practice, 18(1), 56-85.

Gnangnon, S. K. (2019b). Aid for trade and export diversification in recipient-countries. The World Economy, 42(2), 396-418.

Gnangnon, S. K. (2019c). Does the Impact of Aid for Trade on Export Product Diversification depend on Structural economic policies in Recipient-Countries? Economic Issues, 24(1), 59-87.

Gnangnon, S. K. (2019d). Has the WTO's Aid for Trade Initiative Delivered on Its Promise of Greater Mobilization of Development Aid in Favor of the Trade Sector in Developing Countries? The International Trade Journal, 33(6), 519-541.

Helble, M. C., Mann, C. L. and Wilson, J. S. (2012). Aid-for-trade facilitation, Review of World Economics (Weltwirtschaftliches Archiv), 148(2), 357-376.

Hoekman, B., and Shingal, A. (2017). Aid for Trade and International Transactions in Goods and Services'. CEPR Working Paper DP12250, Centre for Economic Policy Research, London.

Hufbauer, G. C., and Lu, Z. (2016). Increased trade: a key to improving productivity, policy brief 16-15. Washington DC: Peterson Institute for International Economics.

Hühne P, Meyer B and Nunnenkamp, P. (2014b). 'Aid for trade: Assessing the effects on recipient exports of manufactures and primary commodities to donors and non-donors', Kiel Working Papers, No 1953. Kiel Institute for the World Economy (IfW), Kiel, Germany.

Hühne, P. Meyer, B., and Nunnenkamp, P. (2014a). Who Benefits from Aid for Trade? Comparing the Effects on Recipient versus Donor Exports. Journal of Development Studies, 50(9): 1275-1288.

Hynes W. and Holden, P. (2016). What future for the Global Aid for Trade Initiative? Towards an assessment of its achievements and limitations. Development Policy Review, 34 (4), 593-619.

Issa, H., and Ouattara, B. (2008). Foreign aid flows and real exchange rate: Evidence from Syria. Journal of Economic Development, 33, 133-146.

Kappeler, A (2015). Estonia: raising productivity and benefitting more from openness. Paris: OECD Economics Department Working Papers 1215.

Kim, Y. R. (2019). Does aid for trade diversify the export structure of recipient countries? The World Economy, 42(9), 2684-2722.

$\mathrm{Li}$, Y., and Rowe, F. (2007). Aid inflows and the real effective exchange rate in Tanzania. (World Bank Policy Research Working Paper 4456). Washington, DC: World Bank. 
Limao, N., and Venables, A. J. (2001). Infrastructure, geographical disadvantage, transport costs, and trade. World Bank Economic Review, 15(3), 451-79.

Martinez-Zarzoso, I., Nowak-Lehmann, F. and Rehwald, K. (2017). Is Aid for Trade Effective? A Panel Quantile Regression Approach. Review of Development Economics, 21(4), e175-e203.

Melitz, M. J. (2003). The impact of trade on intra-industry reallocations and aggregate industry productivity. Econometrica, 71(6), 1695-1725.

Monacelli, T., and Perotti, R. (2010). Fiscal Policy, the Real Exchange Rate and Traded Goods. Economic Journal, 120(544), 437-461.

Nickell, S. (1981). Biases in dynamic models with fixed effects. Econometrica, 49(6), 1399-1416.

Nkusu, M. (2004). Aid and the Dutch disease for low-income countries: Informed diagnoses for prudent prognoses. IMF Working Paper 04/49, International Monetary Fund, Washington, D.C.

Nyoni, T. S. (1998). Foreign aid and economic performance in Tanzania. World Development, 26(7), $1235-1240$.

Odedokun, M. (2003). Analysis of deviations and delays in aid disbursements. Journal of Economic Development, 137(28), 137-169.

Ouattara, B., and Strobl, E. (2008). Foreign aid inflows and the real exchange rate in the CFA franc zone. International Economics, 2008/4 (n¹16), 37 à 51.

Portugal-Perez A., and Wilson, J. S., (2012). Export Performance and Trade Facilitation Reform: Hard and Soft Infrastructure. World Development, 40(7), 1295-1307.

Radelet, S. (2006). A primer on foreign aid. (CGD Working Paper 92). Washington, DC: Center for Global Development.

Rajan, R. G., and Subramanian, A. (2011). Aid, dutch disease, and manufacturing growth. Journal of Development Economics, 94, 106-118

Ravn, M. O., Schmitt-Grohé, S., and Uribe, M. (2012). Consumption, Government Spending, and the Real Exchange Rate. Journal of Monetary Economics, 59(3), 215-234.

Roodman, D. M. (2009). A note on the theme of too many instruments, Oxford Bulletin of Economic and Statistics, 71(1), 135-158.

Sackey, H. (2001). External aid inflows and the real exchange rate in Ghana. AERC Research paper No. 110, African Economic Research Consortium, Nairobi. 
Samuelson P. (1964). Theoretical Notes on Trade Problems. The Review of Economics and Statistics, 46(2), 145-154.

Selaya, P., and Sunesen, E. R. (2012). Does Foreign Aid Increase Foreign Direct Investment? World Development, 40(11), 2155-2176.

Selaya, P., and Thiele, R. (2010). Aid and sectoral growth: Evidence from panel data. Journal of Development Studies, 46, 1749-1766.

Thiele, R., Nunnenkamp, P., and Dreher, A. (2006). Sectoral aid priorities: Are donors really doing their best to achieve the millennium development goals?. Kiel Institute for World Economics Working Paper No. 1266.

Van Wijnbergen, S. (1984). The 'Dutch disease': A disease after all? Economic Journal, 94(373), 41-55.

Vijil, M. (2014). Aid for Trade Effectiveness: Complementarities with Economic Integration. The World Economy, 37(4), 555-566. Special Issue: Aid for Trade Edited by Jaime de Melo.

Vijil, M. and Wagner, L. (2012). Does Aid for Trade Enhance Export Performance? Investigating on the Infrastructure Channel. World Economy 35 (7), 838-868.

Vos, R. (1998). Aid flows and "dutch disease" in a General equilibrium framework for Pakistan. Journal of Policy Modeling, 20,77-109.

White, H., and Wignaraja, G. (1992). Exchange Rates. Trade Liberalisation and Aid: the Sri Lankan Experience, World Development, 20, 1471-1480.

White, H. (1992). The macroeconomic impact of development aid: A critical survey. Journal of Development Studies, 28(2), 163-240.

Wilson, J. S., Mann, C. L., and Otsuki, T. (2003). Trade facilitation and economic development: a new approach to quantifying the impact. World Bank Economic Review, 17(3), 367-89.

Wilson, J. S., Mann, C. L., and Otsuki, T. (2005). Assessing the benefits of trade facilitation: a global perspective. World Economy, 28(6), 841-71.

WTO (World Trade Organization). (2005). Ministerial Declaration on Doha Work Programme. Paper presented at the Sixth Session of Trade Ministers Conference, Hong Kong, China, December 13-18.

Younger, S. (1992). Aid and the dutch disease: Macroeconomic management when everybody loves you. World Development, 20, 1587-1597.

\section{Tables}

Table 1: Effect of the Aid for Trade on Real Exchange Rate 
Estimator. Two-Step System GMM

\begin{tabular}{|c|c|c|c|c|}
\hline Variables & Log(REER) & Log(REER) & Log(REER) & Log(REER) \\
\hline & (1) & (2) & (3) & (4) \\
\hline \multirow{2}{*}{$\bar{L} \log (\mathrm{REER})_{\mathrm{t}-1}$} & $0.426^{* * *}$ & $0.462^{* * *}$ & $0.468 * * *$ & $0.452^{* * *}$ \\
\hline & $(0.0118)$ & $(0.00848)$ & $(0.00891)$ & $(0.00813)$ \\
\hline \multirow[t]{2}{*}{ Log(AfTTOT) } & $-0.0633^{* * *}$ & & & \\
\hline & $(0.00461)$ & & & \\
\hline \multirow[t]{2}{*}{ Log(AfTINFRA) } & & $-0.0308^{* * *}$ & & \\
\hline & & $(0.00249)$ & & \\
\hline \multirow[t]{2}{*}{ Log(AfTPROD) } & & & $-0.0530 * * *$ & \\
\hline & & & $(0.00438)$ & \\
\hline \multirow[t]{2}{*}{ Log(AfTPOL) } & & & & $-0.00781^{* * * *}$ \\
\hline & & & & $(0.00236)$ \\
\hline \multirow[t]{2}{*}{$\overline{\log (\text { NonAfT })}$} & $0.0789 * * *$ & $0.0444^{* * *}$ & $0.0708^{* * *}$ & $0.0160 * * *$ \\
\hline & $(0.00659)$ & $(0.00533)$ & $(0.00640)$ & $(0.00386)$ \\
\hline \multirow[t]{2}{*}{ Log(GFCF) } & $0.0307^{*}$ & $0.0251 *$ & 0.00545 & $0.0468^{* * *}$ \\
\hline & $(0.0159)$ & $(0.0132)$ & $(0.0132)$ & $(0.0104)$ \\
\hline \multirow[t]{2}{*}{$\log (\mathrm{GCONS})$} & $-0.0967 * * *$ & $-0.0590 * * *$ & $-0.101 * * *$ & -0.0181 \\
\hline & $(0.0183)$ & $(0.0153)$ & $(0.0162)$ & $(0.0126)$ \\
\hline \multirow[t]{2}{*}{ Log(OPEN) } & $-0.130 * * *$ & $-0.103^{* * *}$ & $-0.0979 * * *$ & $-0.121 * * *$ \\
\hline & $(0.0160)$ & $(0.0155)$ & $(0.0142)$ & $(0.0123)$ \\
\hline \multirow[t]{2}{*}{ Log(BRMONEY) } & $0.0546 * * *$ & $0.0336 * * *$ & $0.0479 * * *$ & $0.0400 * * *$ \\
\hline & $(0.0104)$ & $(0.00888)$ & $(0.00943)$ & $(0.00936)$ \\
\hline \multirow[t]{2}{*}{$\log (G D P C)$} & $0.0141^{*}$ & 0.00536 & 0.00534 & -0.00147 \\
\hline & $(0.00759)$ & $(0.00595)$ & $(0.00678)$ & $(0.00502)$ \\
\hline \multirow[t]{2}{*}{ Log(TERMS) } & $0.0310 * *$ & $0.0369 * * *$ & $0.0519 * * *$ & $0.0638 * * *$ \\
\hline & $(0.0143)$ & $(0.0120)$ & $(0.0134)$ & $(0.0117)$ \\
\hline \multirow[t]{2}{*}{ Constant } & $2.592^{* * * *}$ & $2.353^{* * *}$ & $2.112^{* * *}$ & $2.235^{* * * *}$ \\
\hline & $\begin{array}{l}(0.167) \\
\end{array}$ & $(0.129)$ & $(0.165)$ & $(0.114)$ \\
\hline Observations - Countries & $602-113$ & $602-113$ & $601-113$ & $568-112$ \\
\hline Number of Instruments & 94 & 94 & 94 & 94 \\
\hline AR1 (P-Value) & 0.0023 & 0.0041 & 0.0042 & 0.0480 \\
\hline AR2 (P-Value) & 0.8454 & 0.4216 & 0.4350 & 0.3487 \\
\hline AR3 (P-Value) & 0.2257 & 0.2069 & 0.1853 & 0.5138 \\
\hline Sargan (P-Value) & 0.2604 & 0.1186 & 0.2088 & 0.2438 \\
\hline
\end{tabular}

Note: ${ }^{*} p$-value $<0.1 ;{ }^{* *} p$-value $<0.05 ;{ }^{* * *} p$-value<0.01. Robust Standard Errors are in parenthesis. In the two-step system GMM estimations, the variables "AfTTOT", "AfTINFRA", "AfTPROD", "AfTPOL", "NonAfT", "GDPC", "GFCF", "OPEN", "GCONS" and "BRMONEY" have been considered as endogenous. Time dummies have been included in the regressions. The regressions have used 3 lags of the dependent variable as instruments, and 2 lags of endogenous variables as instruments.

Table 2: Effect of the Aid for Trade on Real Exchange Rate in LDCs versus NonLDCs Estimator. Two-Step System GMM 


\begin{tabular}{|c|c|c|c|c|}
\hline Variables & Log(REER) & Log(REER) & $\begin{array}{l}\log (\text { REER }) \\
\end{array}$ & Log(REER) \\
\hline & (1) & (2) & (3) & (4) \\
\hline \multirow[t]{2}{*}{$\log (\text { REER })_{\mathrm{t}-1}$} & $0.431 * * *$ & $0.463^{* * *}$ & $0.463^{* * *}$ & $0.454 * * *$ \\
\hline & $(0.0108)$ & $(0.00741)$ & $(0.00732)$ & $(0.00567)$ \\
\hline \multirow[t]{2}{*}{ Log(AfTTOT) } & $-0.0637^{* * *}$ & & & \\
\hline & $(0.00405)$ & & & \\
\hline \multirow[t]{2}{*}{$\mathrm{Log}(\mathrm{AfTTOT}){ }^{*} \mathrm{LDC}$} & $-0.0134 * * *$ & & & \\
\hline & $(0.00430)$ & & & \\
\hline \multirow[t]{2}{*}{ Log(AfTINFRA) } & & $-0.0292 * * *$ & & \\
\hline & & $(0.00224)$ & & \\
\hline \multirow[t]{2}{*}{ [Log(AfTINFRA)]*LDC } & & $-0.0176 * * *$ & & \\
\hline & & $(0.00272)$ & & \\
\hline \multirow[t]{2}{*}{ Log(AfTPROD) } & & & $-0.0476 * * *$ & \\
\hline & & & $(0.00432)$ & \\
\hline \multirow{2}{*}[\mathrm{Log}(\mathrm{AfTPROD})]{$* \mathrm{LDC}$} & & & $-0.0250 * * *$ & \\
\hline & & & $(0.00486)$ & \\
\hline \multirow[t]{2}{*}{ Log(AfTPOL) } & & & & $-0.00441^{* *}$ \\
\hline & & & & $(0.00179)$ \\
\hline \multirow[t]{2}{*}[\mathrm{Log}(\mathrm{AfTPOL})]{$^{*} \mathrm{LDC}$} & & & & $-0.00953^{* * * *}$ \\
\hline & & & & $(0.00279)$ \\
\hline \multirow[t]{2}{*}{ LDC } & $0.198 * * *$ & $0.258 * * *$ & $0.394 * * *$ & $0.0911 * *$ \\
\hline & $(0.0768)$ & $(0.0455)$ & $(0.0748)$ & $(0.0381)$ \\
\hline \multirow[t]{2}{*}{$\log ($ NonAfT $)$} & $0.0759 * * *$ & $0.0428 * * *$ & $0.0635^{* * * *}$ & $0.0102^{* * * *}$ \\
\hline & $(0.00527)$ & $(0.00488)$ & $(0.00505)$ & $(0.00289)$ \\
\hline \multirow[t]{2}{*}{$\overline{\log (\mathrm{GFCF})}$} & $0.0382^{* * * *}$ & $0.0288^{* *}$ & 0.0198 & $0.0641^{* * *}$ \\
\hline & $(0.0130)$ & $(0.0113)$ & $(0.0139)$ & $(0.00941)$ \\
\hline \multirow[t]{2}{*}{$\mathrm{Log}(\mathrm{GCONS})$} & $-0.0876^{* * * *}$ & $-0.0446^{* * *}$ & $-0.0970 * * *$ & 0.00384 \\
\hline & $(0.0144)$ & $(0.0149)$ & $(0.0124)$ & $(0.00989)$ \\
\hline \multirow[t]{2}{*}{ Log(OPEN) } & $-0.118 * * *$ & $-0.0940 * * *$ & $-0.0980 * * *$ & $-0.118 * * *$ \\
\hline & $(0.0123)$ & $(0.0153)$ & $(0.0131)$ & $(0.0101)$ \\
\hline \multirow[t]{2}{*}{ Log(BRMONEY) } & $0.0526^{* * * *}$ & $0.0306^{* * *}$ & $0.0539 * * *$ & $0.0438^{* * *}$ \\
\hline & $(0.00981)$ & $(0.00798)$ & $(0.00650)$ & $(0.00596)$ \\
\hline \multirow[t]{2}{*}{ Log(GDPC) } & -0.00816 & $-0.0156 * *$ & $-0.0178 * *$ & $-0.0243^{* * *}$ \\
\hline & $(0.00730)$ & $(0.00654)$ & $(0.00805)$ & $(0.00754)$ \\
\hline \multirow[t]{2}{*}{ Log(TERMS) } & $0.0497 * * *$ & $0.0501^{* * * *}$ & $0.0624^{* * *}$ & $0.0800^{* * *}$ \\
\hline & $(0.0123)$ & $(0.0108)$ & $(0.0113)$ & $(0.00744)$ \\
\hline \multirow[t]{2}{*}{ Constant } & $2.655^{* * *}$ & $2.402^{* * *}$ & $2.250 * * *$ & $2.267 * * *$ \\
\hline & $(0.140)$ & $(0.131)$ & $(0.116)$ & $(0.119)$ \\
\hline Observations - Countries & $602-113$ & $602-113$ & $601-113$ & $568-112$ \\
\hline Number of Instruments & 104 & 104 & 104 & 104 \\
\hline AR1 (P-Value) & 0.0013 & 0.0033 & 0.0054 & 0.0405 \\
\hline AR2 (P-Value) & 0.9141 & 0.4422 & 0.4045 & 0.2721 \\
\hline AR3 (P-Value) & 0.2294 & 0.2283 & 0.1862 & 0.5786 \\
\hline Sargan (P-Value) & 0.4185 & 0.1785 & 0.3668 & 0.3398 \\
\hline
\end{tabular}

Note: ${ }^{*} p$-value $<0.1 ;{ }^{* *}$-value $<0.05 ;{ }^{* * *} p$-value<0.01. Robust Standard Errors are in parenthesis. In the two-step system GMM estimations, the variables "AfTTOT", "AfTINFRA", "AfTPROD", "AfTPOL", "NonAfT", "GDPC", "GFCF", "OPEN", "GCONS", "BRMONEY" and the interaction variables have been considered as endogenous. Time dummies have been included in the regressions. The regressions have used 3 lags of the dependent variable as instruments, and 2 lags of endogenous variables as instruments. 
Figures

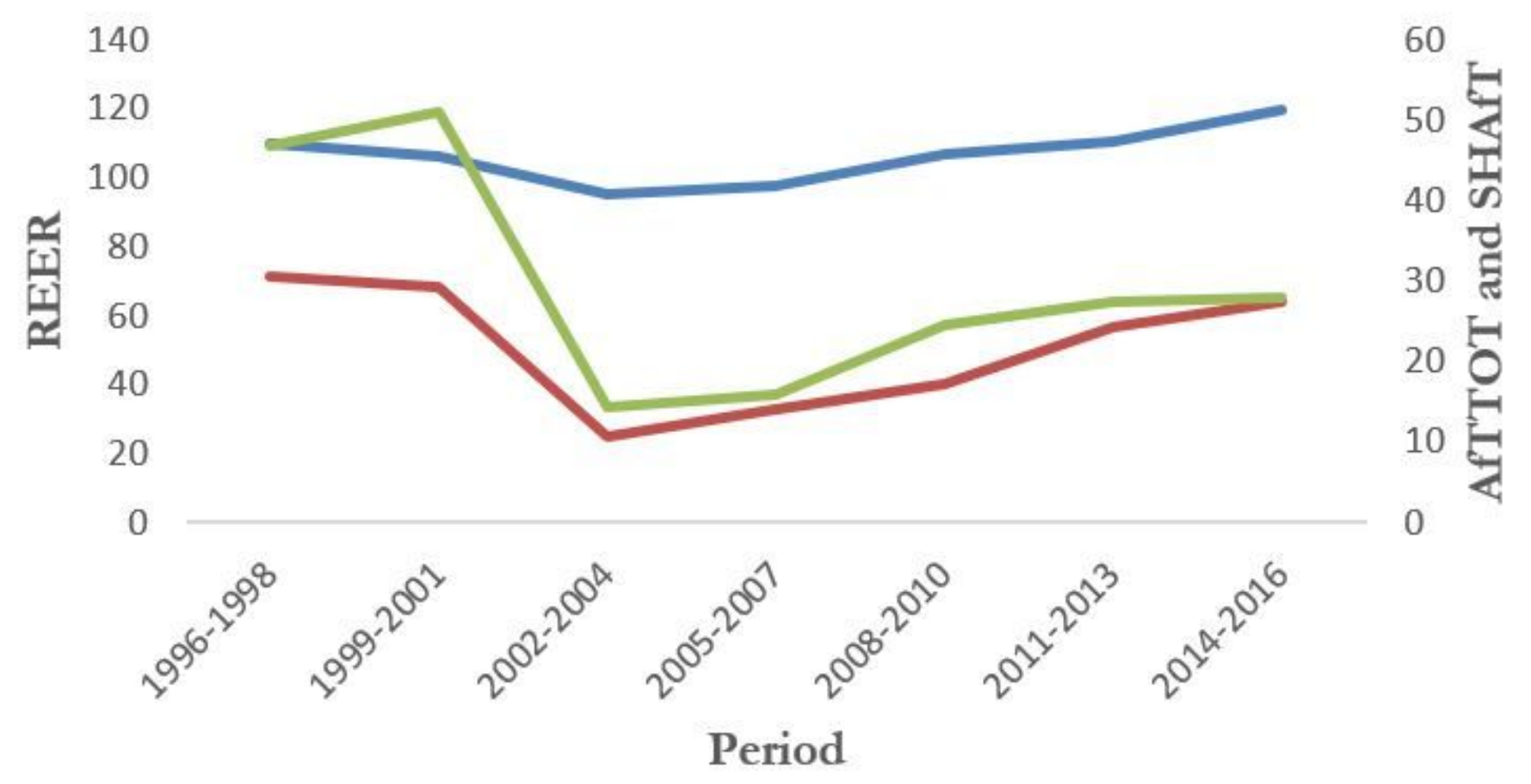

REER_Full Sample AfTTOT_Full Sample SHAfT_Full Sample

Source: Author

Note: "AfT" is expressed in 10 Millions US\$, Constant 2016 Prices.

Figure 1

Developments of AfT and REER

\section{Supplementary Files}

This is a list of supplementary files associated with this preprint. Click to download.

- Appendix1.docx 